\title{
Exploring the impact of non-chemical methods on the control of bulb mite (Rhizoglyphus robini Claparède) and yield of saffron (Crocus sativus L.)
}

\author{
Hassan Rahimi ${ }^{1, \star}$, Mohammad Nateq Golestan $^{1}$ and Ali Kakhki ${ }^{2}$ \\ ${ }^{1}$ Plant Protection Research Department, Khorasan Razavi Agricultural and Natural Resources \\ Research and Education Center, AREEO, Mashhad, Iran \\ ${ }^{2}$ Bio-Protection Research Centre, Lincoln University, PO Box 85084, Lincoln, New Zealand \\ ${ }^{*}$ Corresponding author: h.rahimi@areeo.ac.ir
}

\begin{abstract}
The bulb mite (Rhizoglyphus robini) causes damage to a number of crop and ornamental plant species, including saffron (Crocus sativus). A split-plot experiment based on a randomised complete-block design was conducted between 2011 and 2015 to investigate the effects of solarisation using transparent plastic along with planting date and first irrigation on the population of bulb mite, yield of saffron, size of corms produced and extent of corm infection. Solarisation significantly decreased the mite population and increased the saffron yield $(\mathrm{P}<0.01)$. Increased yields were achieved by planting in June rather than in September. However, the use of irrigation immediately after planting in June increased the mite population and decreased saffron yields. A combination of solarisation in the first year and planting in June of the next year with no irrigation after planting resulted in a reduction of $94 \%$ in the population of the mites and a 3.48-fold increase in saffron yield. In Iran, saffron corms should be planted in June but not irrigated until September. If planting does occur in September then irrigation should be applied immediately after planting.
\end{abstract}

Keywords: Irrigation, solarisation, planting date, mite, saffron.

\section{INTRODUCTION}

The stigmas and styles of Crocus sativus L. flowers are known as saffron and are used to season and colour food. Damage to saffron corms by the mite Rhizoglyphus robini Claparède, 1869 (Acari: Acaridae) results in lower yields of saffron crops grown in Iran (Rahimi et al. 2008; Rahimi \& Kamali 1993). Some farming practices, including solarisation and planting date, have been found to reduce mite populations and increase saffron yield (Rahimi et al. 2013). Rahimi et al. (2008) investigated the effect of two cultivation factors (sowing depth and irrigation time) on bulb mite population and saffron productivity, and found that sowing depth in different seasons affected the bulb mite population. Furthermore, summer irrigation increased the population of corm mites and decreased the leaf-area index of the plants. Mollafilabi \& Shoorideh (2009) found that planting new saffron corms immediately after removing old corms from the soil in June reduced costs of tillage and increased production. These results were supported by those of Ghobadi et al. (2015) who also found that planting corms in June increased saffron yields. Koocheki et al. (2011) investigated the effects of planting date and irrigation in spring, summer and autumn with the use of cover crops on yield of saffron leaves as a forage crop. They found that the highest leaf-area index and leaf yield were obtained following spring planting. They also showed that irrigation after planting decreased 
forage yield by $10 \%$ compared with no irrigation. However, the response of plants to irrigation differed with planting season. The highest leafarea index and forage yield were obtained by avoiding irrigation after planting in either spring or summer whereas irrigation after planting in autumn increased leaf area index (Koocheki et al. 2011). In addition, Koocheki et al. (2015) indicated that planting in autumn generated more environmental stress on the corms than planting in spring, which can affect the number, time of onset and the growth rate of buds responsible for the creation of new corms and, consequently, on the weight of new saffron corms. Koocheki et al. (2016) investigated the effects of planting time and irrigation management on the average weight of new corms produced, which is the most important factor affecting saffron yield. They found that corm cultivation during the plant's rest period (summer) and avoiding summer irrigation until early August increased the weight of new corms produced.

Soil sterilisation and solarisation procedures cause physical, chemical and biological changes to soil and many researchers have acknowledged the benefits of these methods on crop production (e.g. Gerson \& Smiley 1990; Katan 1992 and Ono et al. 1993). The solarisation method used by Gerson \& Smiley (1990) involved covering the soil with a layer of transparent plastic to reduce the population of $R$. robini mites in fields of Gladiolus spp. and Allium sativum L. (garlic). They found that mites disappeared to a depth of $20 \mathrm{~cm}$ after 10 days and to $30 \mathrm{~cm}$, after 20 days. The authors recommended a one-month solarisation period for complete disinfestation. Ono et al. (1993) recommended the same treatment against $R$. robini mite infestation of onion fields in Japan. Moreover, Katan (1992) reported that soil solarisation with transparent plastic reduced the population of pathogenic agents in the soil. Mousavi \& Taymoory (1992) showed that the population of Pratylenchus spp. nematodes reduced to zero after 40 days in some treatments involving covering dry soil with transparent plastic sheets in the hot season for 20 to 40 days. Ahmadian Yazdi (2002) stated that solarisation in field and greenhouse conditions contributed to a decline of Meloidogyne spp. nematodes by $88 \%$. Rahimi et al. (2013) investigated the effects of soil solarisation against bulb mite on saffron yield and showed that a combination of solarisation treatment for 30 days (from June 20 to July 20) followed by immediate planting was the best treatment in terms of reducing mite population and increasing saffron yield.

Saffron corms are traditionally planted in September due to the reduction of activities of farmers, and also to a limited extent in June, without solarisation of soil. The best time for solarisation of soil is in July (Rahimi et al. 2013) and, once solarisation has been undertaken, saffron can be planted in September of the same year or June and September of the next year. As outlined above, previous studies have shown that irrigation immediately after planting can have detrimental effects so the aim of this study was to determine the amount of time needed from the end of solarisation to planting time and timing of irrigation to reach the lowest population of mite and the highest saffron yield. Accordingly, in this study, the effects of solarisation, planting date and irrigation after cultivation on mite population and saffron yield were evaluated.

\section{METHODS}

This experiment was carried out at the Agriculture and Natural Resources Research Station of Gonabad city $\left(34^{\circ} 22^{\prime} \mathrm{N}, 58^{\circ} 45^{\prime} \mathrm{E}\right)$ in Iran from 2011 to 2015. Part of a 3-ha field was selected for the trial. The field had a long history of saffron cultivation in which the $R$. robini population was known to be high (an average of 20 mites per 100 grams of saffron corms). The field was irrigated in mid-June 2011 and existing saffron corms were removed immediately afterwards. Sequentially, 20 metric tonnes per hectare of cow manure were spread and mixed with soil by rototiller. At this time, 30 soil samples per hectare were taken using an auger to a soil depth of $20 \mathrm{~cm}$. Then, to collect mites, $100 \mathrm{~g}$ of each soil sample was placed in the Berlese funnel for 72 hours. On 22 June 2011, three replicates of the seven crop management treatments with or without solarisation, a total of 
42 experimental plots with dimensions of $4 \times 3 \mathrm{~m}$, were created then transparent plastic was placed on solarisation-treatment plots (21 plots) for 30 days. No action was taken on non-solarisationtreatment plots. Seven crop-management treatments were then established in sub-plots: (1) planting without irrigation in September 2011; (2) irrigation immediately after planting in September 2011; (3) planting without irrigation in June 2012; (4) irrigation immediately after planting in June 2012; (5) planting in June 2012 and irrigation in August 2012; (6) planting without irrigation in September 2012; and (7) irrigation immediately after planting in September 2012. In each experimental unit, $6 \mathrm{~kg}$ of corms were planted (5 metric tonnes per hectare) at $5-\mathrm{cm}$ spacing within rows and $25 \mathrm{~cm}$ between rows and at a depth of $18 \mathrm{~cm}$. All other operations (irrigation, shallow cultivation, weed control, etc.) were conducted in the same way in all treatments until the end of the project. Additional irrigation was applied to all treatments as follows: before flowering (in early November); after flowering (in mid-December); once or twice during winter (in February and March); and in the middle of April each year.

To estimate the population of the mites, three soil samples (diameter and depth of $25 \mathrm{~cm}$ ) along with associated saffron plants were taken from each experimental unit in early April, during the second, third and fourth year of cultivation (20122014 in plots cultivated in September 2011 and also 2013-2015 in saffron plots cultivated in June and September 2012). These samples were transferred to the laboratory in nylon bags. In the laboratory, a defined and uniform weight of saffron corms without soil (100 g) was transferred to a Berlese funnel for 72 hours to collect the mites. The number of mites in each sample was determined using a stereomicroscope and recorded.

Dried stigma weight of flowers in each experimental unit harvested in mid-November to mid-December of 2011 to 2014 was determined. The mean weights were converted to kilogram per hectare (dry stigma).

All corms in a square metre in the middle of each plot were collected in the last year of the study to determine the damage caused by mites. Damage occurs as dark spots on a corm and is detectable after removing the bundle of skin around the corm. Collected corms were divided into three groups: large corms $(>8 \mathrm{~g})$; medium corms (5-8 g); and small corms ( $<5 \mathrm{~g})$. The percentage and weight of damaged corms were determined and calculated.

\section{Statistical analysis}

All data were analysed statistically. The experiment was conducted in split plots based on a randomised complete block design with three replicates for each treatment in three plots separately and lasted for three years. In total, 42 plots were considered in this experiment for two main plots (solarisation) and seven subplots (crop management) and three experimental replications. The variance residues were normal at $5 \%$ level. Analysis of variance was done for all data. Comparison of the means, based on the Least Significant Difference (LSD) test was performed at 5\% level using SAS (version 9.1.3) software.

\section{RESULTS AND DISCUSSION \\ Effects of solarisation treatment}

The effect of solarisation treatment on the mean of saffron yield and mite population was significant $(\mathrm{P}<0.01) \quad$ regardless of crop-management treatment (Tables $1 \& 2$; Figs. $1 \& 2$ ). The average of mite population from non-solarised plots in the first, second, third years was: 23,53 and 270 per 100 grams of saffron corms respectively, with a mean over three years of 115 mites. The corresponding number of mites from solarisation treated plots was 3,12 and 105 respectively, with a mean over three years of 40 mites. The mean data corresponded to a $65.13 \%$ decrease in mite population as a result of solarisation treatment. The average saffron yield from non-solarised plots in the first, second, third years was 0.61, 2.21 and 1.94, respectively (average 3 years was $1.58 \mathrm{~kg} /$ ha). Corresponding values for the solarisationtreated plots were $0.50,3.75$ and 3.04, respectively (average 3 years was $2.43 \mathrm{~kg} / \mathrm{ha}$ ). Therefore, there was an increase of $56.9 \%$ per hectare in dried stigma weight as a result of the solarisation 
Table 1 Analysis of variance (mean square) for the populations of the bulb mite and saffron yield in different years

\begin{tabular}{|c|c|c|c|c|c|c|c|c|c|}
\hline \multirow[b]{2}{*}{ Source of Variance } & \multirow[b]{2}{*}{ (df) } & \multicolumn{4}{|c|}{$\begin{array}{l}\text { Mean square of the number of mites per } \\
100 \text { grams of saffron corm }\end{array}$} & \multicolumn{4}{|c|}{$\begin{array}{l}\text { Mean square of saffron yield } \\
(\mathrm{kg} / \mathrm{ha})\end{array}$} \\
\hline & & $\begin{array}{l}2012- \\
2013 \\
\end{array}$ & $\begin{array}{l}2011- \\
2012\end{array}$ & $\begin{array}{l}2014- \\
2015\end{array}$ & Average & $\begin{array}{l}2011- \\
2012\end{array}$ & $\begin{array}{l}2012- \\
2013\end{array}$ & $\begin{array}{l}2013- \\
2014 \\
\end{array}$ & Ave \\
\hline Replication & 2 & $12.67 \mathrm{~ns}$ & $17.23 \mathrm{~ns}$ & $1286.38 \mathrm{~ns}$ & 187.10ns & $0.01 \mathrm{~ns}$ & $0.08 \mathrm{~ns}$ & $0.35 \mathrm{~ns}$ & $0.08^{*}$ \\
\hline Solarisation (Sol.) & 1 & $4180.02^{* *}$ & $17405.36^{* *}$ & * $285532.59^{* *}$ & $12734.37^{* *}$ & $0.12^{\star}$ & $25.01^{\star *}$ & $12.94^{\star *}$ & $7.56^{\star *}$ \\
\hline Error 1 & 2 & 12.67 & 31.71 & 374.95 & 80.16 & 0.004 & 0.02 & 0.06 & 0.004 \\
\hline Crop-management $(\mathrm{M})$ & 6 & $378.86^{* *}$ & $4636.56^{* *}$ & $62594.56^{* *}$ & ${ }^{*} 10348.83^{* *}$ & $0.66^{* *}$ & $11.82^{* *}$ & $1.08^{\star *}$ & $2.33^{* *}$ \\
\hline Sol. $\times M$ & 6 & $206.08^{* *}$ & $1740.86^{* *}$ & $24291.32^{\star *}$ & * $2179.38^{* *}$ & $0.21^{\star *}$ & $0.81^{* *}$ & $0.51^{\star *}$ & $0.14^{\star *}$ \\
\hline Error2 & 24 & 2.60 & 29.42 & 491.72 & 82.75 & 0.01 & 0.50 & 0.05 & 0.02 \\
\hline $\mathrm{CV}(\%)$ & & 12.60 & 16.52 & 11.81 & 11.68 & 17.44 & 7.54 & 8.60 & 6.80 \\
\hline
\end{tabular}

${ }^{* *},{ }^{*}$ and ns: significant at $0.01,0.05$, and non-significant

Table 2 Comparison of effects of solarisation treatment on the mean of saffron yield and mite population

\begin{tabular}{lllll}
\hline \multirow{2}{*}{ Year } & \multicolumn{2}{c}{ Number of mites $/ 100 \mathrm{~g}$ corms } & \multicolumn{2}{c}{ Yield kg/ha } \\
\cline { 2 - 5 } & Non-solarised & Solarised & Non-solarised & Solarised \\
\hline 1 & $23 \pm 2.90$ & $3.048 \pm 0.499$ & $0.611 \pm 0.096$ & $0.503 \pm 0.063$ \\
3 & $53.19 \pm 9.88$ & $12.476 \pm 2.37$ & $2.205 \pm 0.277$ & $3.749 \pm 0.326$ \\
mean & $270.286 \pm 44.67$ & $105.143 \pm 15.09$ & $1.935 \pm 0.109$ & $3.045 \pm 0.124$ \\
\hline
\end{tabular}

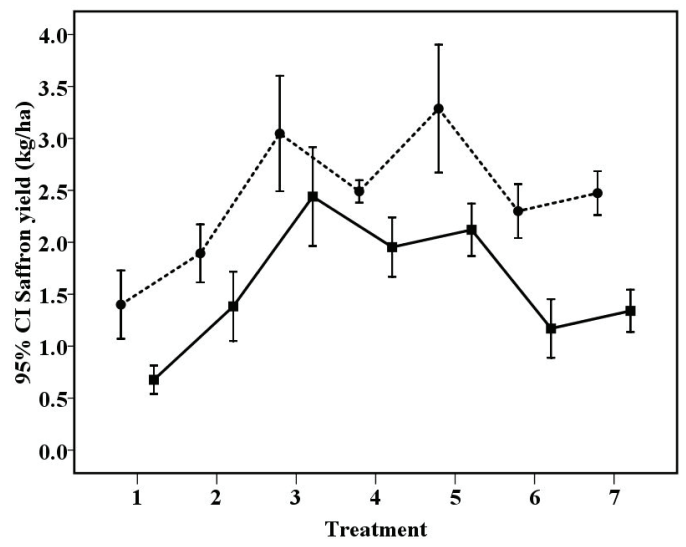

Figure 1 Comparison of average yield of saffron $(\mathrm{kg} / \mathrm{ha})$ in three years for two solarisation treatments and seven types of crop management. Data points offset from $\mathrm{x}$ axis for clarity.

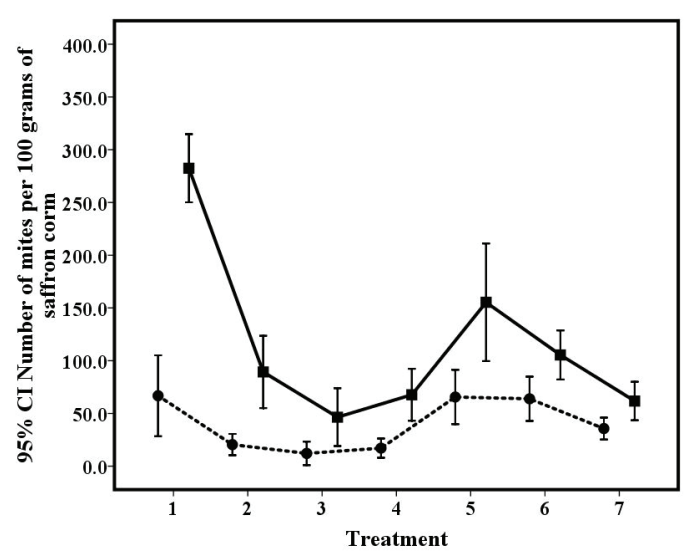

Figure 2 Comparison of the average population of saffron mites in three years for two solarisation treatments and seven types of crop management. Data points offset from $\mathrm{x}$ axis for clarity. 
treatment. The reduction in mite population and increase in saffron yield as a result of solarisation were consistent with results obtained previously by Rahimi et al. (2013). Over their three-year study, the authors found a 2.74-fold decrease in mite population and a 2.78-fold increase in saffron yield following a 30-day solarisation treatment of soil.

In the last year of the current study, mean percentages of the infected corms (the number of the black spots) and percentages of weight and the size of small corms was significantly lower $(\mathrm{P}<0.01)$ following solarisation (Table 3$)$.

The results obtained here are consistent with the reduction of mite populations in gladioli and garlic fields (Gerson \& Smiley 1990) and onion fields (Ono et al. 1993) following solarisation treatment. Furthermore, Mauromicale et al. (2010) suggested solarisation as a useful and environmentally friendly soil-disinfestation method that increases the yield of tomatoes. More recently, Gill et al. (2017) have reviewed the benefits of solarisation for pest control of crops in various parts of India.

\section{Effects of crop-management treatment}

In this experiment, the saffron yield in the second year was more than the third year, while under normal conditions the yield in the third year should be higher than in the second year. Interestingly, the average recorded yield of saffron for Gonabad city were 4.5, 4.0 and 3.2 $\mathrm{kg} / \mathrm{ha}$ respectively in 2012-2014. (Anonymous, 2013; Anonymous, 2014; Anonymous, 2015a \& Anonymous, 2015b). Also, precipitation in 2011, 2012 and 2013 for the study area was 95.7, 141.2 and $79.7 \mathrm{~mm}$ respectively (Anonymous, 2015b). Therefore, due to the growth of the saffron and its flowering (harvest) in early autumn, the high amount of rainfall in the second year may have affected saffron yield of the third year.

All data for mite population and saffron yield were averaged over three years. The lowest mean three-year mite population (29.28 mites per 100 grams of corms) occurred following implementation of crop-management Treatment 3 (planting in June 2012 and no irrigation). In contrast, the highest mite population (146.80 mites per 100 grams of corms) occurred following the Treatment 1 (planting in Sept. 2011 and no irrigation) (Table 4; Fig. 2) although the mite population was lower following planting in Sept 2012 and no irrigation than in Sept 2011 and no irrigation $84.67 \mathrm{cf}$. 146.80 . Also, Treatment 3 (planting in June 2012 and no irrigation) resulted in the second highest saffron yield with $2.74 \mathrm{~kg}$ dried stigmas per hectare (Fig. 1). This was only slightly lower than for Treatment 5 (planting in June 2012 and irrigation in August 2012), which yielded $2.77 \mathrm{~kg}$ dried stigma per hectare. The

Table 3 ANOVA for mean percentages of the infected saffron corms to R. robini and mean percentages of weight and quantities of saffron corms in the last year of the study (in June 2015)

\begin{tabular}{|c|c|c|c|c|c|c|c|c|c|c|c|}
\hline \multirow{2}{*}{$\begin{array}{l}\text { Source of } \\
\text { Variance }\end{array}$} & \multicolumn{5}{|c|}{$\begin{array}{l}\text { Mean square of the percentages of } \\
\text { the infected saffron corms } / \mathrm{m}^{2}\end{array}$} & \multicolumn{3}{|c|}{$\begin{array}{c}\text { Mean square of corm } \\
\text { weight } / \mathrm{m}^{2}\end{array}$} & \multicolumn{3}{|c|}{$\begin{array}{l}\text { Mean square of the } \\
\text { corm numbers } / \mathrm{m}^{2}\end{array}$} \\
\hline & $(\mathrm{df})$ & $>8 \mathrm{~g}$ & $5-8 \mathrm{~g}$ & $<5 \mathrm{~g}$ & mean & $>8 \mathrm{~g}$ & $5-8 g$ & $<5 \mathrm{~g}$ & $>8 \mathrm{~g}$ & $5-8 \mathrm{~g}$ & $<5 \mathrm{~g}$ \\
\hline Block & 2 & is & $0.02 \mathrm{~ns}$ & $0.06 \mathrm{~ns}$ & as & $28.99 \mathrm{~ns}$ & $5.51 \mathrm{~ns}$ & $9.59 \mathrm{~ns}$ & $40.66 \mathrm{~ns}$ & $4.88 \mathrm{~ns}$ & $23.31 \mathrm{~ns}$ \\
\hline 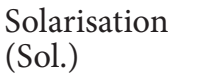 & 1 & 27. & 5 & 2 & $36.07^{* *}$ & $84.35^{\star *}$ & 5 & $273.97^{* *}$ & In & 2 & 28 \\
\hline rror1 & 2 & 08 & 0.32 & 12 & 0.01 & 7.18 & 13. & 2.08 & 27.31 & 20.16 & 2.05 \\
\hline $\begin{array}{l}\text { anage- } \\
\text { I.) }\end{array}$ & 6 & $9.97^{\star *}$ & $23.80^{\star *}$ & $16.19^{x}$ & 13.1 & $741.41^{* *}$ & 222.2 & 80. & $347.13^{\star}$ & 162 & 111.7 \\
\hline Sol. $\times$ M. & 6 & $1.80^{\star \star}$ & $7.91^{\star \star}$ & $3.86^{\star *}$ & $2.83^{\star *}$ & $120.76^{* *}$ & $37.76^{\star *}$ & $128.66^{* *}$ & $128.45^{\star *}$ & $76.67^{\star *}$ & $247.87^{* *}$ \\
\hline Error2 & 24 & 0.17 & 0.13 & 0.08 & 0.02 & 9.05 & 3.31 & 4.87 & 9.22 & 5.68 & 9.60 \\
\hline $\mathrm{V}(\%)$ & & 20.68 & 13.95 & 13.66 & 6.40 & 5.68 & 6.79 & 10.93 & 9.03 & 7.79 & 8.46 \\
\hline
\end{tabular}

**,* and ns: significant at $0.01,0.05$, and non-significant 
Table 4 Mean comparison between the effects of crop management on the bulb mite populations and the average yields of saffron in different years

\begin{tabular}{|c|c|c|c|c|c|c|c|c|c|c|}
\hline \multirow{2}{*}{$\begin{array}{l}\text { Crop- } \\
\text { management }\end{array}$} & \multirow{2}{*}{$\begin{array}{l}\text { Planting } \\
\text { Month }\end{array}$} & \multirow{2}{*}{$\begin{array}{l}\text { Irrigation } \\
\text { time }\end{array}$} & \multicolumn{4}{|c|}{ Number of mites/100 g of corms } & \multicolumn{4}{|c|}{ Saffron yield $(\mathrm{kg} / \mathrm{ha})$} \\
\hline & & & $\begin{array}{l}2012- \\
2013 \\
\end{array}$ & $\begin{array}{l}2013- \\
2014 \\
\end{array}$ & $\begin{array}{l}2014- \\
2015 \\
\end{array}$ & age & $\begin{array}{l}2011- \\
2012 \\
\end{array}$ & $\begin{array}{l}2012- \\
2013 \\
\end{array}$ & $\begin{array}{l}2013- \\
2014 \\
\end{array}$ & Average \\
\hline 1 & Sept & none & $26.83^{\mathrm{a}}$ & $83.83^{\mathrm{a}}$ & $329.70^{\mathrm{a}}$ & $146.80^{\mathrm{a}}$ & $0.38^{\mathrm{cd}}$ & $0.90^{\mathrm{f}}$ & $1.82^{\mathrm{d}}$ & $1.03^{e}$ \\
\hline 2 & $\mathrm{Se}$ & 11 & $18.83^{\mathrm{b}}$ & $45.50^{\mathrm{b}}$ & $183.80^{\mathrm{b}}$ & $82.72^{c}$ & $1.07^{\mathrm{a}}$ & $1.64^{\mathrm{e}}$ & $2.19^{c}$ & $1.63^{\mathrm{d}}$ \\
\hline 3 & Jur & one & $4.50^{\mathrm{f}}$ & $7.66^{\mathrm{d}}$ & $75.67^{d}$ & $29.28^{\mathrm{e}}$ & $0.95^{\mathrm{a}}$ & $4.28^{\mathrm{b}}$ & $2.99^{\mathrm{a}}$ & $2.74^{\mathrm{a}}$ \\
\hline 4 & June 2 & June 2012 & $8.00^{\mathrm{e}}$ & $9.83^{\mathrm{d}}$ & $109.30^{c}$ & $42.39^{d}$ & $0.23^{\mathrm{e}}$ & $3.86^{\mathrm{c}}$ & $2.57^{\mathrm{b}}$ & $2.22^{\mathrm{b}}$ \\
\hline 5 & June 2012 & Aug 2 & $6.66^{\mathrm{f}}$ & $8.33^{\mathrm{d}}$ & $317.20^{\mathrm{a}}$ & $110.40^{\mathrm{b}}$ & $0.57^{\mathrm{b}}$ & $4.73^{\mathrm{a}}$ & $3.00^{\mathrm{a}}$ & $2.77^{\mathrm{a}}$ \\
\hline 6 & Sept 2012 & none & $16.00^{c}$ & $43.33^{\mathrm{b}}$ & $194.70^{\mathrm{b}}$ & $84.67^{c}$ & $0.27^{\mathrm{de}}$ & $2.60^{\mathrm{d}}$ & $2.33^{\mathrm{bc}}$ & $1.73^{\mathrm{cd}}$ \\
\hline 7 & Sept 2012 & Sept 2012 & $10.33^{\mathrm{d}}$ & $31.33^{c}$ & $104.50^{\mathrm{cd}}$ & $48.72^{\mathrm{d}}$ & $0.40^{c}$ & $2.79^{\mathrm{d}}$ & $2.51^{\mathrm{b}}$ & $1.90^{c}$ \\
\hline
\end{tabular}

The means followed by same letters in each column are not significantly different (LSD, $\mathrm{P}<0.05) .1$ - Planting without irrigation in September 2011; 2- Irrigation immediately after planting in September 2011; 3- Planting without irrigation in June 2012; 4- Irrigation immediately after planting in June 2012; 5- Planting in June and irrigation in August 2012; 6- Planting without irrigation in September 2012; and 7- Irrigation immediately after planting in September 2012.

lowest yield was obtained following Treatment 1 , which is consistent with the high mite population for this treatment. The mite populations in plots irrigated immediately after planting in June 2012 (Treatment 4) or shortly after (in August 2012, Treatment 5) were higher than for un-irrigated plots planted at the same time (Treatment 3, Table 4). It is possible that irrigation in the summer created favourable biological conditions for pest growth and reproduction. The yields of stigmas were also lower for Treatments 4 and 5 compared with Treatment 3 (possibly due to mite damage of saffron corms). In contrast, irrigation immediately after planting in September of either the current year (Treatment 2) or the following year (Treatment 7 ) reduced the mite population (possible due to cooling of the soil) and increased saffron yield (possibly due to the creation of ideal conditions at the start of saffron natural activity) compared with un-irrigated treatments (Treatment 1 and 6 respectively). These results are consistent with the results of Koocheki et al. (2011) who used saffron forage as one of the determinants of yield. They found that the response of plants to irrigation was not the same in all seasons, i.e. the forage yield decreased by $10 \%$ with irrigation after planting in June but increased with irrigation following planting in
September. Moreover, Koocheki et al. (2016) investigated the characteristics of new saffron corms in response to irrigation and planting date. According to them, the average weight of new corms was the most important factor affecting the yield of saffron and this was maximised by: (a) the planting of saffron corms during the resting period; (b) avoiding irrigation after planting; and (c) avoiding summer irrigation in August.

There were significant differences $(\mathrm{P}<0.01)$ in the mean weight and size of saffron corms with crop-management treatment (Table 3). Also, the lowest level of corm infection $(0.69 \%)$ was observed following cultivation of June without irrigation after planting and the highest level (59.4\%) was observed following cultivation of September with irrigation immediately after planting (Table 5). Sadeghi et al. (2003) claimed that the irrigation of saffron farms in August increased the yield by $17 \%$ to $30 \%$. Rahimi et al. (2008) found almost the same results in the first year of the experiments, but the results reversed in subsequent years. It seems that the increase in product is due to cooling effect of irrigation on the soil and compensating for the lack of moisture content of the saffron field that reduces the damaging effects of excessive drought during the dormancy period of the saffron corms in 
Table 5 Mean comparison between the effects of crop management on the mean percentage of the infected saffron corms due to $R$. robini and mean percentages weight and quantities of saffron corms in the last year of the study (in April 2015)

\begin{tabular}{lccccccccccc}
\hline $\begin{array}{l}\text { Crop } \\
\text { Man- } \\
\text { agement }\end{array}$ & \multicolumn{3}{c}{ Infected saffron corm $(\%) / \mathrm{m}^{2}$} & \multicolumn{3}{c}{ Corm weight $(\%) / \mathrm{m}^{2}$} & \multicolumn{4}{c}{ The number of corms $(\%) / \mathrm{m}^{2}$} \\
\cline { 2 - 11 } & $>8 \mathrm{~g}$ & $5-8 \mathrm{~g}$ & $<5 \mathrm{~g}$ & Average & $>8 \mathrm{~g}$ & $5-8 \mathrm{~g}$ & $<5 \mathrm{~g}$ & $>8 \mathrm{~g}$ & $5-8 \mathrm{~g}$ & $<5 \mathrm{~g}$ \\
\hline 1 & $0.75^{\mathrm{d}}$ & $0.97^{\mathrm{e}}$ & $0.61^{\mathrm{e}}$ & $0.78^{\mathrm{f}}$ & $38.80^{\mathrm{d}}$ & $36.45^{\mathrm{a}}$ & $24.75^{\mathrm{a}}$ & $22.22^{\mathrm{c}}$ & $37.19^{\mathrm{a}}$ & $40.50^{\mathrm{a}}$ \\
2 & $2.13^{\mathrm{c}}$ & $3.05^{\mathrm{c}}$ & $3.12^{\mathrm{b}}$ & $2.76^{\mathrm{c}}$ & $51.25^{\mathrm{b}}$ & $26.36^{\mathrm{c}}$ & $22.40^{\mathrm{ab}}$ & $30.85^{\mathrm{b}}$ & $28.65^{\mathrm{bc}}$ & $40.50^{\mathrm{a}}$ \\
3 & $0.65^{\mathrm{d}}$ & $0.91^{\mathrm{e}}$ & $0.52^{\mathrm{e}}$ & $0.69^{\mathrm{f}}$ & $48.27^{\mathrm{c}}$ & $37.56^{\mathrm{a}}$ & $14.16^{\mathrm{c}}$ & $37.19^{\mathrm{ab}}$ & $40.27^{\mathrm{a}}$ & $22.54^{\mathrm{c}}$ \\
4 & $4.12^{\mathrm{a}}$ & $3.80^{\mathrm{b}}$ & $2.50^{\mathrm{c}}$ & $3.47^{\mathrm{b}}$ & $60.44^{\mathrm{a}}$ & $24.83^{\mathrm{cd}}$ & $14.73^{\mathrm{c}}$ & $39.71^{\mathrm{a}}$ & $30.48^{\mathrm{b}}$ & $29.82^{\mathrm{b}}$ \\
5 & $2.89^{\mathrm{b}}$ & $1.67^{\mathrm{d}}$ & $1.21^{\mathrm{d}}$ & $1.92^{\mathrm{d}}$ & $61.84^{\mathrm{a}}$ & $22.33^{\mathrm{d}}$ & $15.83^{\mathrm{c}}$ & $41.64^{\mathrm{a}}$ & $26.96^{\mathrm{c}}$ & $31.40^{\mathrm{b}}$ \\
6 & $0.92^{\mathrm{d}}$ & $1.12^{\mathrm{e}}$ & $1.42^{\mathrm{d}}$ & $1.16^{\mathrm{e}}$ & $53.91^{\mathrm{b}}$ & $24.55^{\mathrm{cd}}$ & $21.54^{\mathrm{b}}$ & $33.94^{\mathrm{b}}$ & $27.65^{\mathrm{bc}}$ & $38.42^{\mathrm{a}}$ \\
7 & $2.37^{\mathrm{bc}}$ & $6.29^{\mathrm{a}}$ & $5.10^{\mathrm{a}}$ & $4.59^{\mathrm{a}}$ & $60.50^{\mathrm{b}}$ & $19.44^{\mathrm{e}}$ & $20.07^{\mathrm{b}}$ & $40.88^{\mathrm{a}}$ & $21.86^{\mathrm{d}}$ & $37.26^{\mathrm{a}}$ \\
\hline
\end{tabular}

The means followed by same letters in each column are not significantly different $(\mathrm{LSD}, \mathrm{P}<0.05)$. Treatments: 1- Planting without irrigation in September 2011; 2- Irrigation immediately after planting in September 2011; 3- Planting without irrigation in June 2012; 4- Irrigation immediately after planting in June 2012; 5- Planting in June and irrigation in August 2012; 6- Planting without irrigation in September 2012; and 7- Irrigation immediately after planting in September 2012.

the summer. Nevertheless, if irrigation becomes standard practice in saffron cultivation, it will provide appropriate biological conditions for infection and, after a few years, corm damage could become the most serious problem of saffron farms. Such issues have already been reported anecdotally in many areas where summer irrigation has been promoted. Therefore, irrigation in summer is not recommended.

Results for leaf area and leaf yield from an experimental design comparing June and September planting dates showed the highest leaf area index and saffron forage yield were obtained following spring planting (Kookheki et al. 2011). Moreover, Mollafilabi \& Shoorideh (2009) stated that planting saffron immediately after removing corms from the soil and cultivating them in June not only led to a reduction in costs but also an increase in yield. Furthermore, Ghobadi et al. (2015) confirmed that the cultivation date of June would increase saffron yields.

\section{Effects of solarisation and crop-management treatments}

The combined effect of solarisation and crop-management treatment on the average population of the bulb mite and saffron yields in different years was significant $(\mathrm{P}<0.01$; Table 1) as was the number of the black spots and size of small corms but not for medium or large corms (Table 3). Solarisation of the soil and planting in June without irrigation resulted in the lowest mite population levels, the highest yield of saffron and the least infection of saffron corms with $0.29 \%$ (Figs. 1, 2 \& 3) while the greatest infection rate $(6.80 \%)$ was observed in non-solarisation treated plots where corms were planted in September of the second year with irrigation immediately after planting (Fig. 3).

\section{CONCLUSION}

Solarisation using transparent plastic should be performed on fields for one month after removing all the old saffron corms in late June, followed by planting of new corms the following year. Saffron corms should be planted in June rather than in September but irrigation should be avoided. If, for some reason, planting did occur in September, then irrigation should be done not later than one week after planting.

\section{REFERENCES}

Ahmadian Yazdi A 2002. The disinfections by soil solarization and common methods for Root- 


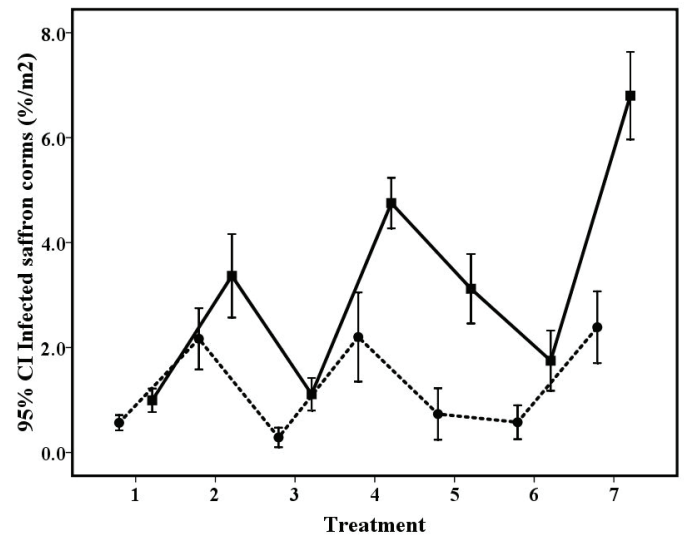

Figure 3 Comparison of the average percentage of the infected corms in the last year of the study for two solarisation treatments and seven types of crop management. Data points offset from $x$ axis for clarity.

knot nematode (Meloidogyne spp.). Final Report Agriculture and Natural Resources Research Center of Khorasan Razavi. 33p. (In Persian).

Anonymous 2013. Statistical Yearbook of Agriculture 2013. Agriculture Organization of Khorasan Razavi province. www. Koaj.ir, (In Persian).

Anonymous 2014. Statistical Yearbook of Agriculture 2014. Agriculture Organization of Khorasan Razavi province. www. Koaj.ir, (In Persian).

Anonymous 2015a. Statistical Yearbook of Agriculture 2015. Agriculture Organization of Khorasan Razavi province. www. Koaj.ir, (In Persian).

Anonymous 2015b. Meteorological data unit Gonabad city. (In Persian).

Gerson U, Smiley RL 1990. Acarine Biocontrol Agents. An illustrated key and manual. Chapman and Hall, London, 174p.

Ghobadi F, Ghorbani Javid M, Sorooshzadeh A 2015. Effects of planting date and corm size on flower yield and physiological traits of saffron (Crocus sativus L.) under Varamin plain climatic conditions. Saffron Agronomy \& Technology 2(4): 265-276 (In Persian with
English Summary).

Gill HK, Aujla Iqbal S, De Bellis L, Luvisi A 2107. The role of soil solarization in India: how an unnoticed practice could support pest control. Frontiers in Plant Science 8: \#1515, $14 \mathrm{p}$.

Katan J 1992. Soil solarization research as a model for the development of new methods of disease control. Phytoparasitica 20: Supplemental 133-135.

Koocheki A, Rezvani Moghaddam P, Fallahi J, Aghvany Shajari M 2011. The effects of planting date and irrigation of spring, summer and fall with the use of cover crops on forage yield of saffron. The first national conference on strategies to achieve sustainable agriculture, Ahvaz, Khuzestan province PNU. http://www.civilica.com/ Paper-CAAMSA01-CAAMSA01_127.html. (In Persian with English summary).

Koocheki AR, Rezvani-Moghaddam P, Fallahi HR 2015. Effects of planting dates, irrigation management and cover crops on growth and yield of saffron (Crocus sativus L). Agroecology (Accepted for Publication). (In Persian with English Summary).

Koocheki A, Rezvani Moghaddam P, Fallahi HR, Aghhavani M 2016. The study of saffron (Crocus sativus L.) replacement corms growth in response to planting date, irrigation management and companion crops. Saffron Agronomy \& Technology 4(1): 3-18.

Mollafilabi A, Shoorideh H 2009. The new method of saffron production. 4th National Festival of Saffron. Zaveh, Iran. 27-28 October 2009.

Mauromicale G, Lo Monaco A, Longo AMG 2010. Improved efficiency of soil solarization for growth and yield of greenhouse tomatoes. Agronomy for Sustainable Development 30: 753-761. Available online at: www. agronomy-journal.org

Mousavi M, Taymoory F 1992. Evaluate the effects of the solar heat and the plastic coating on weed populations and soil nematodes in vegetable fields. The first seminar vegetable research. Karaj, 99-98. (In Persian). 
Ono M, Ando S, Morita S 1993. Control of the bulb mites $R$. robini Claparede and Caloglyphus spp. on Chinese chive Allium tuberosum by solar heating. Proceedings of the Association of Plant Protection of Kyushu 39: 117-118.

Rahimi H, Kamali K 1993. Laboratory studies on biology of bulb mite Rhizoglyphus robini (Acari: Acaridae) and its damages on saffron corm in Gonabad and Qaen. The Scientific Journal of Agriculture 16: 53-63. (In Persian with English summary).

Rahimi H, Mokhtarian A, Bazoobandi M, Rahimi H, Kiani M, Behdad M 2008. Effects of sowing depth and summer irrigation on Rhizoglyphus robini (Acari: Acaridae) population in Gonabad. Applied Entomology and Phytopathplogy 76(1): 1-12. (In Persian with English summary).

Rahimi H, Dadmand M, Torabi E, Rahimi H, Torabi H, Araghi M 2013. Investigating the effects of soil solarization on saffron field against bulb mite (Rhizoglyphus robini). Plant Protection (Scientific Journal of Agriculture) 36(2): 1-15. (In Persian with English summary).

Sadeghi B, Aghamiri A, Negari A 2003. Adopting summer irrigation to increase saffron yield. Proceedings of the 3rd National Saffron Congress. Mashhad, Iran. Pp. 171-172. (In Persian). 